\title{
Opportunities in Housing Property for Young and First-Time Homebuyer in Malaysia
}

\author{
Mohammad Mujaheed Hassan, Nobaya Ahmad, Ahmad Hariza Hashim
}

To Link this Article: http://dx.doi.org/10.6007/IJARBSS/v12-i1/12004 DOI:10.6007/IJARBSS/v12-i1/12004

Received: 17 November 2021, Revised: 19 December 2021, Accepted: 28 December 2021

Published Online: 12 January 2022

In-Text Citation: (Hassan et al., 2022)

To Cite this Article: Hassan, M. M., Ahmad, N., \& Hashim, A. H. (2022). Opportunities in Housing Property for Young and First-Time Homebuyer in Malaysia. International Journal of Academic Research in Business and Social Sciences, 12(1), 942-955.

\section{Copyright: (c) 2022 The Author(s)}

Published by Human Resource Management Academic Research Society (www.hrmars.com)

This article is published under the Creative Commons Attribution (CC BY 4.0) license. Anyone may reproduce, distribute, translate and create derivative works of this article (for both commercial and non0-commercial purposes), subject to full attribution to the original publication and authors. The full terms of this license may be seen at: http://creativecommons.org/licences/by/4.0/legalcode

\section{Vol. 12, No. 1, 2022, Pg. $942-955$}

Full Terms \& Conditions of access and use can be found at http://hrmars.com/index.php/pages/detail/publication-ethics 


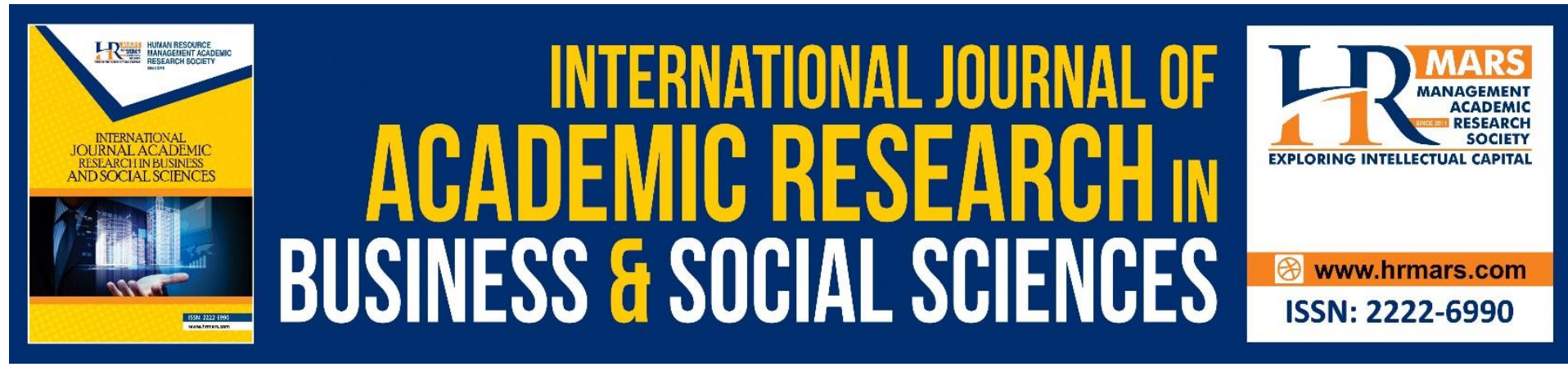

\title{
Opportunities in Housing Property for Young and First-Time Homebuyer in Malaysia
}

\author{
Mohammad Mujaheed Hassan, Nobaya Ahmad, Ahmad \\ Hariza Hashim \\ Faculty of Human Ecology, Universiti Putra Malaysia, Malaysia \\ Email: mujaheed@upm.edu.my
}

\begin{abstract}
The biggest concern for first-time buyers is affordability, especially in major Malaysian cities such as Klang Valley, Penang and Johor. Low and middle-income families are worried because affordability will not only affect their ability to become homeowners, but also the size and type of houses they can buy. In order to solve the problem of affordability of real estate, the Malaysian government has provided two key programs for the relatively new workforce. However, most young and first-time buyers are not aware of these offers. This article aims to review the opportunities for young and first-time homebuyers to own a home. This article first reviews young and time homebuyers, the definition of housing, housing loans, the support provided by the Malaysian government for first-time homebuyers in terms of affordable housing and financial support.
\end{abstract}

Keywords: First Time, Home Buyer, Affordability, Housing Scheme

\section{Introduction}

The house is a necessity, and it plays an important role for everyone. Everyone needs a place to stay, get proper rest in their own way, feel comfortable, and live a convenient life. The home is also called the social unit formed by the family living together (Hong \& Yew, 2012 in Mariadas et al., 2019). According to Petrus (2012), the house is the most important basic need for human survival. Some individuals may purchase housing property only for investment purposes, while others aim to upgrade their lifestyles. At the same time, people may purchase housing property impulsively as a competitive advantage over others (Hassan, et al., 2021a). In addition, Petrus also stated houses can indicate people's living standards and social status. However, according to Hong \& Yew (2012), housing affordability is affected by the cost of living in Malaysia and rising housing prices, especially for middle-income earners. Because of the uneven income level, they cannot cope with the cost of living. Therefore, buyers need to make a good choice to buy a house. Especially for first-time home buyers, because they have no previous home buying experience. According to Khan et al (2017), the problem of homebuyers is crucial because they are limited by affordability and choosing the right option for them to meet their needs. Therefore, this research study aimed to review the opportunities for young and first-time homebuyers to own a home in Malaysia. The discussion of the research study starts with the elaboration of opportunities in housing development in 
Malaysia which includes the new, subsale and auction property. Next, the research study discussed housing loan opportunities and followed by the discussion on government support for first-time homebuyers in Malaysia.

\section{Literature Review}

There are several definition of "housing" by scholar and researcher. Housing is defined as the basic spatial scale of the objective living environment (Huang \& Du, 2015). In terms of improving the quality of life, housing is one of the important elements needed by mankind (National Housing Department, 2010). The plan of most families is mainly to own a house, not only for shelter, but also for comfort. It also defines personal success, and housing becomes more important for expressing family needs and the family's most unique investment (Hashim, 2010). The house described can also be regarded as a place where humans live. It is a simple hut or house complex. Regardless of the degree of internal architectural interest, it is a real house, providing shelter and acting as the focus of daily life (Ahsen and Gulcin, 2005). According to Abram (1964), "housing is not only a residence, but also a part of the entire environment and social environment living structure". It involves many aspects of economic activity and development. Therefore, housing provides indicators of social connections, a good image, a sense of belonging, and social status (Khalifah et al., 2015).

According to Doling (2006), young people represent the 20 to 35 age group. This age range can be transformed into a personal family that is independent of parents and starts to build one's own (Leh et al., 2016). Young people who mainly live in urban areas are currently facing the main problem of owning a house because house prices are rising so fast that they cannot afford it (Leh et al., 2016; Hassan, et al., 2021b). Heath (2018) stated that young people usually adopt a "live for today" attitude towards financial planning. Saving is considered an "adult" behavior. Young people's financial knowledge level is often lower than average, and they are unable to obtain financial services at any time. Leaving your parents' home usually triggers a greater sense of financial responsibility (Heath, 2008). Vliet (1998) raised the issue of high housing costs that has caused young people to prefer renting a house rather than buying a house. Compared with other age groups, young people are more likely to experience homelessness and renting problems (Tan, 2009). In addition, most people own their first home in their 30s or late 20s (Tan, 2009). Therefore, this suggests that many young people are particularly unlikely to own or buy a house. For example, a study of 250 young ( $<40$ years old) Malaysian government workers (Zaimah et al., 2012) found that only $40 \%$ of respondents own their own houses. The housing problem in Malaysia is more about accessibility for lowincome groups (Junaidi, et al., 2012), including young people. This is about the reduced supply of low-cost or affordable housing and the low income levels of locals (Junaidi et al., 2012).

It raises the question on the housing preference of young generation with their financial limitation. Therefore, Housing and Local Government Minister Datuk Abdul Rahman Dharran (Bernama News, 2014) stated that the Malaysian government has advanced the proposal of a "youth city" in Malaysia to benefit forty (40) Malaysians under the age of to buy cheaper and affordable goods. houses. Despite the Malaysian government's efforts to increase the home ownership rate of all income levels, especially low-income groups, the real needs of residents for the housing environment may be overlooked to a certain extent (Fan, 2010). Khozaei (2012) suggested that the variable that affects housing priority as housing quality can prove people's desires, their actual situation, and the relevance of this to their ideal residence. 


\section{Methodology}

This study is in the archival category, with its outline serves as a review of the empirical literature on the opportunities in a housing property for young and first-time homebuyers in Malaysia. The relevant data of this study is obtained through second-hand materials, namely academic journals, conference papers, articles, textbooks, etc. These materials are collected from Malaysian real estate and investment experts.

\section{Discussion}

\section{Housing Property in Malaysia}

\section{a) New property in Malaysia}

The Malaysian real estate market favors the concept of "sale and build", that is, developers start selling before the construction project begins. For home buyers, when they buy off-theplan properties from developers, they usually cross their fingers and hope for the best results. If they are lucky, they will get a pretty good unit, even if it is not a perfect unit, and once the project is completed, they may see a significant increase in value. Due to discounts and rebates provided by developers, newly launched properties belonging to the primary market or some people call units under construction are welcomed by home buyers. It is easy to spot new development projects in the location chosen by the buyer. For all developer projects, buyers only need to walk into their offices or sales offices, or easily identify them at real estate exhibitions or conferences.

There are many discounts for a brand new property because it is in the developer's interest to sell all units as soon as possible. From early-bird discounts, first-time home purchase discounts to Very-Very Important Person (VVIP) discounts, homebuyers are sure to get some kind of discount. Developers' brand-new properties usually have a defect liability period of up to 24 months. The owner has the right to request the developer to correct any defects in the unit, such as leaks in the bathroom, cracks in the wall, or improper installation of door hinges. The buyer will become the first owner of the property. From fixtures and accessories to painting work on the installation, everything will be in its best condition. Knowing that no previous occupants can provide the owner with psychological peace.

However, buying a property under construction means that buyers have to wait three to four years for completion. During this period, the bank's homebuyer credit was locked in the total loan amount, making it difficult to buy another property. Since the project has not yet been completed, buyers do not know exactly what it will look like. Buyers must choose their units and anticipate market demand. This includes the possibility of developing projects, such as highways and public facilities, such as bus stations built in front of their homes. Therefore, since buyers buy real estate according to plans and models, the quality cannot be guaranteed. There are also cases where developers abandon the project due to a lack of funds. This is why it is important to choose reputable developers when buying off-plan properties.

\section{b) Subsale Properties in Malaysia}

Sub sale properties are purchased from previous homeowners (most likely individuals) on the open or secondary market. When buying a sub sale property, it is important to ensure that the owner is the legal owner of the property. Buyers can obtain all relevant information about the property by conducting a land ownership search on the property in the relevant land office, and obtain confirmation from the registered owner and whether the property has any encumbrances. By investing in sub sale properties, homebuyers know what they actually get 
with the money they paid. When buying a property through a newly launched property, buyers can only imagine what it will look like. But for the completed properties, buyers can really take a look at the scenery. Buyers no longer have to guess what it will do. Buyers can see the unit, landscape, decoration and your neighbors. Most importantly, real data such as rent and transaction prices will be provided. Buying resale will enable buyers to rent them out immediately and collect rent to pay their mortgages. If the homebuyers are lucky, buyers may also have existing tenants paying rent at market prices. Renting tenants without having to spend money on real estate agency fees can already save you money. The completed property is ready for home buyers to play the role of landlord. Whereas, there is always a risk that a newly released product will not be completed on time, or the developer may completely abandon the project. Once a buyer has locked a suitable property, it usually only takes about two months to execute the legal paperwork before the buyer can move into the property.

Finding a good sub sale transaction means that buyers need to look at a series of individual units under various conditions. Buyers will have to repeatedly check the condition of the unit, market valuation and property rent until they find a suitable one. Buyers also need to negotiate with different owners, agents and lawyers. Buyers may face some seller risks when they almost complete the transaction. The seller may not want to sell the property or may increase the price. If the price is higher than the bank's valuation, buyers will have to pay for the lack of price. Cheap doesn't really mean good. If the seller is too keen to get rid of the property that is willing to get rid of a substantial price cut, then buyers should be careful. Home buyers don't want to end up having to deal with a property where a previous crime or murder has occurred, or if the previous owner obtains a loan from an illegal money lender with that address. Table 1 shows the upfront cost of properties under construction and resale in Malaysia. 
Table 1: Upfront cost for under construction and subsale property

\begin{tabular}{|c|c|c|}
\hline Upfront Cost & Under construction property & Subsale property \\
\hline Down payment & $\begin{array}{l}\text { Minimum } 10 \% \text {, but the } \\
\text { developer may offer a discount } \\
\text { or rebate, allowing you to fork } \\
\text { out a lower (or zero) down } \\
\text { payment. }\end{array}$ & Minimum $10 \%$. \\
\hline $\begin{array}{l}\text { Sale \& Purchase } \\
\text { Agreement (SPA) } \\
\text { legal fees }\end{array}$ & \multirow{4}{*}{$\begin{array}{l}\text { The developer may offer to } \\
\text { cover some or all of your legal } \\
\text { fees and stamp duty. } \\
\text { Homebuyers may fork out fewer } \\
\text { upfront costs, as the developer } \\
\text { may offer discounts and rebates } \\
\text { to offset down payment, or } \\
\text { cover part of the other upfront } \\
\text { fees. }\end{array}$} & $\begin{array}{l}\text { First RM500,000: } 1 \% \\
\text { Next RM500,000: } 0.8 \% \\
\text { Next RM2,000,000: } 0.7 \% \\
\text { Next RM2,000,000: } 0.6 \% \\
\text { Next RM2,500,000: } 0.5 \%\end{array}$ \\
\hline $\begin{array}{l}\text { Stamp Duty on } \\
\text { SPA \& } \\
\text { Memorandum of } \\
\text { Transfer }\end{array}$ & & $\begin{array}{l}\text { First RM100,000: } 1 \% \\
\text { RM101,000 - RM500,000: 2\% } \\
\text { RM500,001 - RM1 million: 3\% } \\
\text { Above RM1 million: } 4 \%\end{array}$ \\
\hline $\begin{array}{l}\text { Loan Agreement } \\
\text { legal fees }\end{array}$ & & $\begin{array}{l}\text { First RM500,000: } 1 \% \\
\text { Next RM500,000: } 0.8 \% \\
\text { Next RM2,000,000: } 0.7 \% \\
\text { Next RM2,000,000: } 0.6 \% \\
\text { Next RM2,500,000: } 0.5 \%\end{array}$ \\
\hline $\begin{array}{l}\text { Stamp Duty on } \\
\text { Loan agreement }\end{array}$ & & $0.5 \%$ of loan amount \\
\hline Valuation fees & No valuation fees & $\begin{array}{l}\text { First } \mathrm{RM} 100,000=0.25 \% \\
\text { Next residue up to } \mathrm{RM} 2 \text { million }= \\
0.2 \%\end{array}$ \\
\hline $\begin{array}{l}\text { Real estate agent's } \\
\text { fees }\end{array}$ & $\begin{array}{l}\text { No real estate agent's fees as } \\
\text { the transaction of will be direct } \\
\text { between homebuyer and the } \\
\text { developer }\end{array}$ & $\begin{array}{l}\text { About } 2 \% \text { to } 3 \% \text { of property } \\
\text { price }\end{array}$ \\
\hline Miscellaneous & $\begin{array}{l}\text { Mortgage insurance (MRTA) and } \\
\text { fire insurance, utilities deposit, } \\
\text { repair and renovation costs, etc. }\end{array}$ & $\begin{array}{l}\text { Mortgage insurance (MRTA) and } \\
\text { fire insurance, utilities deposit, } \\
\text { repair and renovation costs, etc. }\end{array}$ \\
\hline
\end{tabular}

\section{c) Auction Market in Malaysia}

Generally, auction properties in Malaysia can be obtained at a price less than $20 \%$ of the market value. In some cases, the price may be much lower. When the beneficial owner fails to repay the loan installments for three consecutive months, it constitutes an event of default, and the bank will instruct the lawyer to sell the property by auction. The lawyer will then proceed to instruct the appraiser to prepare a valuation report for the specific property and appoint a private auctioneer (if the final ownership of the property has not been released). Otherwise, the lawyer will apply to the court for a sale order, and then the lawyer will have to appoint an appraiser to prepare the appraisal report and obtain an order from the court to appoint a court auctioneer. From appraiser to private auctioneer/forensic auctioneer, the process takes several months, depending on the efficiency of each department. Then, the auctioneer/forensic auctioneer will notify the sales announcement or sales conditions at least one to two months in advance. This gives the public plenty of time to prepare and inspect the 
property. If the beneficial owner wants to pay and claim back his property, he can do so before the auction date. When the property is auctioned, the value of the property will increase slightly.

Since it is an auction case, the appraiser must give two values in the report, namely market value and forced sale value. Unless requested by the customer, the mandatory sale value usually does not appear in the valuation report. Forced sale value refers to the amount that can be reasonably obtained from the sale of property under the conditions of forced sale that do not meet all the standards of normal market transactions. Forced sale is defined as the sale of property under special circumstances, usually reflecting inappropriate marketing periods without reasonable publicity, inappropriate sales methods, sometimes reflecting the seller's unwillingness, and/or disposal under coercion or coercion. Therefore, based on experience, the forced sale value is usually $20 \%$ lower than its market value. If there are no bidders on the auction day, the lawyer will usually fix another auction date after 30 days. However, this time the reserve price will be $10 \%$ lower than the previous reserve price because there were no bidders in the first round. If there are no bidders for the second time, the property price will be reduced by another $10 \%$, and the third auction date will be normally determined after 30 days.

If homebuyers are looking for a below market value (BMV) property, then this will present a very good opportunity for the homebuyers. When buying a BMV, homebuyers will need to attend an auction in court and prepare a bank draft in advance to show interest. This will cost homebuyers around $10 \%$ of the reserve price. For example, if the property is being auctioned off at RM200,000, homebuyers will need to prepare a RM20,000 bank draft. If homebuyers have successfully bid for the property, homebuyers will need to settle the balance of the payment within 120 days. However, there are many hidden costs, for example, legal, quit rent, unpaid utilities and maintenance fees, assessments and so on. Perhaps the biggest risk is that when the property is legally owned by the buyer, the buyer may find it difficult to evict the tenant or owner. The buyer may have to apply through a lawyer for a court order to evict the resident. This process may take up to four weeks for home buyers, and the cost is between RM1,500 and RM2,000.

\section{Housing Loan}

Housing loans refer to the generation of debts that are mortgaged on the property in which the debts are generated (Hassan, et al., 2021b). Therefore, a housing loan is a kind of credit provided by a bank to an individual to purchase a self-owned house by using the specific house as a deposit for the loan amount. Generally, in Malaysia, buyers can get a mortgage of up to $90 \%$ when buying the first two properties, and $70 \%$ when buying the third and above properties. Therefore, the value of real estate will continue to increase and will hardly depreciate (San, 2016). The ratio of loan approvals to applications reached its highest in 2014, but began to decline in 2016 . The minimum ratio is $41 \%$, and the number of loan approvals in 2016 was 41,579 (Bank Negara Malaysia, 2016). This ratio shows that Malaysians are experiencing difficulties in obtaining and obtaining bank loans. When measuring financial capabilities, the ability to repay loans is also an important consideration (Leh et al., 2016). Common reasons for rejecting housing loan applications are i) the borrower is already heavily in debt; ii) the borrower's remaining income is very small after taking into account the monthly living expenses and existing financial obligations; iii) the borrower's credit history is poor, and iv) Documents are not sufficient to support the ability to repay loan obligations. 
Therefore, in January 2019, Bank Negara Malaysia (BNM) launched to open up RM1 billion of affordable housing funds to more first-time homebuyers. The plan was introduced to help first-time homebuyers, especially homebuyers in low-income groups and small cities, obtain financing for the property. Starting in September 2019, the program has been opened to buyers with a monthly household income of up to RM4,360. Previously, the upper limit of eligibility was a monthly household income of less than RM2,300. Buyers can also use the plan to purchase houses up to RM300,000 each. This is twice the previous limit of RM150,000. Compared with existing loans, the program will help first-time homebuyers reduce their monthly mortgage installments by as much as $23 \%$. Participating financial institutions under the plan include AmBank (M) Bhd, Bank Simpanan Nasional, CIMB Bank Bhd, Malayan Banking Bhd and RHB Bank Bhd.

First-time homebuyers may not know it, but buying and financing a home takes more than just the deposit and the loan. It also involves miscellaneous fees and charges that include:

i. Stamp duty for the transfer of ownership title (also known as a memorandum of transfer or MOT) $=1 \%$ for the first RM100,000; $2 \%$ on the next RM400,000, and $3 \%$ on the subsequent amount;

ii. Sale \& Purchase Agreement (SPA) legal fees = $1 \%$ for first RM500,000, $0.8 \%$ for the next $\mathrm{RM} 500,000$ and $0.5 \%$ to $0.7 \%$ for subsequent amount;

iii. Stamping for SPA = Less than RM100;

iv. SPA legal disbursement fee $=A$ few hundred ringgit;

v. Loan agreement legal fees $=1 \%$ for first RM500,000 (of loan amount), $0.8 \%$ for the next RM500,000 and $0.5 \%$ to $0.7 \%$ for subsequent amount;

vi. Stamp duty for loan agreement $=0.5 \%$ of loan amount;

vii. Loan Facility Agreement legal disbursement fee = A few hundred ringgit;

viii. Fee for transfer of ownership title $=\mathrm{A}$ few hundred ringgit;

ix. Government tax on legal agreements $=6 \%$ of total lawyer fees;

x. $\quad$ Bank processing fee for loan $=\mathrm{RM} 50$ to $\mathrm{RM} 200$.

Table 2 shows Malaysia's main initial costs and estimates of monthly installment housing loans, with an interest rate of $4.5 \%$ and a maturity of 35 years. Since most financial experts recommend that you allocate no more than one-third of your total income to repay the mortgage, this means that the home buyer or home buyer's family should have at least RM6,390 monthly income to be able to afford RM500,000. However, under normal circumstances, if the personal credit score is relatively good, Malaysian banks usually allow individuals to hold loans up to $70 \%$ of their income (including car loans, personal loans, etc.), but individuals should perform mathematical calculations and understand how to take such loans. Financial impact before the action. 
Table 2: Housing Property Estimated Major Initial Costs and Monthly Instalment Payable Home Loan

\begin{tabular}{c|c|c|c|c|c|c|c}
\hline $\begin{array}{c}\text { Purchase } \\
\text { price } \\
\text { (RM) }\end{array}$ & $\begin{array}{c}\text { Down } \\
\text { payment } \\
(\mathbf{1 0 \% )} \\
\text { (RM) }\end{array}$ & $\begin{array}{c}\text { SPA } \\
\text { legal } \\
\text { fees } \\
\text { (RM) }\end{array}$ & $\begin{array}{c}\text { Stamp } \\
\text { duty } \\
\text { on } \\
\text { MOT } \\
\text { (RM) }\end{array}$ & $\begin{array}{c}\text { Loan } \\
\text { agreement } \\
\text { legal fees } \\
\text { (RM) }\end{array}$ & $\begin{array}{c}\text { Stamp } \\
\text { duty for } \\
\text { loan } \\
\text { agreement } \\
\text { (RM) }\end{array}$ & $\begin{array}{c}\text { Total of } \\
\text { Major } \\
\text { Initial } \\
\text { Cost } \\
\text { (RM) }\end{array}$ & $\begin{array}{c}\text { Monthly } \\
\text { instalment } \\
\text { (RM) }\end{array}$ \\
\hline $300 \mathrm{k}$ & 30,000 & 3,000 & 5,000 & 2,700 & 1,350 & 42,050 & 1,278 \\
\hline $400 \mathrm{k}$ & 40,000 & 4,000 & 7,000 & 3,600 & 1,800 & 56,400 & 1,704 \\
\hline $500 \mathrm{k}$ & 50,000 & 5,000 & 9,000 & 4,500 & 2,250 & 70,750 & 2,130 \\
\hline $600 \mathrm{k}$ & 60,000 & 5,800 & 12,000 & 5,320 & 2,700 & 85,820 & 2556 \\
\hline $700 \mathrm{k}$ & 70,000 & 6,600 & 15,000 & 6,040 & 3,150 & 100,790 & 2,982 \\
\hline $800 \mathrm{k}$ & 80,000 & 7,400 & 18,000 & 6,760 & 3,600 & 115,760 & 3,407 \\
\hline
\end{tabular}

\section{Government's Support for First-Time Homebuyers}

\section{a) The initiative of affordable housing}

More than ten years ago, housing prices were still affordable. Today, property prices have risen two to three times, and young people's wages have not caught up with the rise in property prices. Therefore, affordability is the primary task and concern of young buyers. In order to solve the problem of affordability of real estate, the Malaysian government has provided a program for the relatively new workforce. The government has launched housing programs such as Perumahan Rakyat 1Malaysia (PR1MA), MyHome, Skim Rumah Pertamaku (SRP), Skim Perumahan Belia, and Program Perumahan Rakyat (PPR).

Perumahan Rakyat 1Malaysia (PR1MA) is a house developed by Perbadanan PR1MA Malaysia (established under the PR1MA Decree 2012), suitable for middle-income earners; more importantly, even if buyers are already homeowners, they can still take advantage of the plan. However, they should own no more than one other house to remain eligible. PR1MA aims to plan, develop, construct and maintain affordable lifestyle housing for middle-income families in major urban centres. The government plans to build affordable housing in Malaysian cities and towns. Malaysian citizens (individuals or families) with an average monthly household income between RM2,500 and RM7,500 can apply. Applicants must be at least 21 years old at the time of application. A person who currently owns no more than one property. PR1MA houses are allocated through a public voting process. There will be a 10year moratorium, during which no real estate can be sold or transferred to another party without PR1MA's prior approval. The suspension is to ensure that people do not buy for investment reasons alone, as the program is designed to assist in the purchase of self-owned homes. Therefore, PR1MA also stated that the house is for owner-occupied only, which means you are also not allowed to rent it out. The property must be occupied at the time of purchase.

The MyHome program is supervised by the Ministry of Urban Wellbeing, Housing and Local Government. The program is aimed at first-time aspiring homeowners who belong to the low- and middle-income category. It operates similarly to PR1MA, and approved applications still need to go through the voting process. The plan helps buyers by providing subsidies of up to RM30,000, while providing developers with construction incentives to help lower the purchase price of low- and medium-priced houses. First-come, first-served, interested buyers should apply as soon as possible, but please note that even if the individual is a qualified buyer, the application still needs to be reviewed by the Ministry before it can be 
selected by lottery. Like PR1MA, the property may not be sold for 10 years and is intended to be occupied by the owner. The fact is that although these programs are very much needed and fully appreciated for the cause of home ownership, not every applicant who deserves it will benefit from this opportunity. In addition, most of these plans come with a special set of regulations, which may vary from state to state. There is no doubt that those whose applications are rejected will feel frustrated, because these aid programs do bring a lot of hope. However, do not be delayed by the possibility of rejection; instead, arm yourself with as much information as possible to ensure that your application is reliable. In addition, please keep in mind that some of these initiatives are still solving problems and in the pilot phase. Applicants need to be aware of any changes in details that may affect homebuyer's situation from time to time.

Residensi Wilayah was once known as Rumah Mampu Milik Wilayah Persekutuan (RUMAWIP). The government plans to build approximately 80,000 RUMAWIP units in Wilayah Persekutuan within five years. The target buyers are low- and middle-income groups living and working in the Federal Territories (Kuala Lumpur, Putrajaya and Labuan). The types of properties offered are studio apartments and two- or three-room strata residences. The monthly household income of the joint borrower does not exceed RM15,000, and the monthly household income of the single borrower does not exceed RM10,000. There are three types of houses under RUMAWIP. They are i) Rumah Harga Rendah - The minimum area of these types of houses is 700 square feet (three bedrooms), the price of Labuan is 52,000 ringgit, and the price of Kuala Lumpur and Putrajaya is 63,000 Ringgit; ii) Rumah Harga Sederhana Rendah-These three-bedroom houses have a minimum area of 800 square feet and cost between RM63,001 and RM150,000; iii) Rumah Harga Sederhana - These twobedroom homes have a minimum size of $650 \mathrm{sq} f \mathrm{ft}$ and are priced from RM150,001 to RM300,000.

In addition, the government has also introduced Perumahan Awam DBKL. The target tenants are low-income groups living or working in Kuala Lumpur. As long as they do not have houses within 35 kilometers of the city centre, they can rent low-cost houses. Only married borrowers can apply. If they want, renters can buy a house later. The property provided is PPR MTEN (Public Housing Unit), with studio units, 1-3 room units. Medium low-cost housing (available for purchase at Gombak 2, Kuang/Kenari, Seri Pangkor and Seri Tioman 1). The household income of low-cost houses does not exceed RM3,000 per month, while the household income of low-cost houses does not exceed RM4,000 per month. The same scheme introduced for Selangor is Skim Rumah Selangorku (IPR 15). The target buyers are middle-income groups in Selangor, and they can own houses worth no more than RM250,000. Single borrowers can also apply. The types of properties offered are Type A: 700 square feet, Type B: 750-799 square feet, Type C: $800-899$ square feet, 900-999 square feet and 18×60 square feet, Type D: 1000 square feet and $20 \times 60$ square feet, the family income of Type $A$ houses does not exceed RM3,000, and the family income of Type B, C and D houses is RM3,001 to RM10,000 per month. Skim Perumahan Mampu Milik Pulau Pinang (PMM) is for Penangites. The target buyers are low- and middle-income groups who were born or live and work in Penang and are registered voters in Penang, who can buy houses on the island. The attribute types provided are A, B, C1, C2, and C3. Type A houses: the highest price of RM42,000, Type $B$ houses: the highest price of RM72,500, Type $C 1$ houses: the highest price of RM150,000, Type C2 houses: the highest price of RM200,000 and Type C3 houses: the highest price of RM300,000. Income requirements for Type A houses: Family income does not exceed RM2,500, Type B houses: Family income does not exceed RM3,500, Type C1 houses: 
Family income does not exceed RM6,000, Type C2 houses: Family income does not exceed RM8,000 And C3 type house: Family income does not exceed RM10,000.

\section{The initiative of Financial Support}

Besides offering initiative of affordable housing Malaysian government also given financial assistance such as Government Housing Loan Scheme, My First Home Scheme, Rent to Own Scheme (RTO), Real Property Gains Tax (RPGT) and Youth Housing Scheme under BSN. All government officials are eligible to apply for a government housing loan with a fixed interest rate of $4.00 \%$ from "Lembaga Pembiayaan Perumahan Sektor Awam (LPPSA)". The approved loan amount is based on loan eligibility/house price/application amount / outstanding bank loan/market value, whichever is lower. It brings many benefits to government work, and this is one of them. These loans have attractive interest rates and special subsidies and are easier to obtain approval. Compared with traditional bank loans, interest savings and other assistance make the cost of owning a house cheaper. The loan amount depends on the worker's wage level, which can be considered quite good. It is between RM120,000 and RM600,000, with the latter still being able to buy "good houses" in downtown Selangor.

The government announced my first home plan in the 2011 budget to help young people who have just joined the labor market buy their first residential property. The program allows young people to obtain up to $100 \%$ of financing from financial institutions. The plan has some key criteria and benefits, namely $100 \%$ financing, that is, no down payment of $10 \%$ is required. Only for residential properties in Malaysia. Malaysian citizens, under the age of 35. The total monthly income of a single borrower does not exceed RM5,000, and the total monthly income of joint borrowers does not exceed RM10,000 (based on the maximum monthly total income of each borrower of RM5,000). The property value is between RM100,000 to RM400,000. The property must be occupied at the time of purchase. The financing period does not exceed 40 years or does not exceed 65 years. The instalment payment is paid through monthly salary deductions. Compulsory fire insurance/Takaful. Only amortization tool, no redrawing function.

The Rent to Own (RTO) plan was announced in Malaysia's 2020 budget on October 11, 2019. The plan allows Malaysians to own property through lease, and can choose to end up for sale. The biggest selling point of the RTO program is that buyers will be able to lock in the purchase price of the property based on the current selling price. With RTO, buyers can purchase a house after 5 years, even if the current market value of the property is higher due to the capital appreciation over the years, but the selling price remains the same. Financial institutions will provide 10 billion ringgits of financing, of which $30 \%$ of the 3 billion ringgits will be guaranteed by the government. The applicant can rent it for up to 5 years before deciding whether to buy it at the agreed price. However, it only applies to properties up to RM500,000. Applicants will be exempted from stamp duty for SPA and loan agreement. RTO caters to aspiring homeowners who find it difficult to come up with the initial $10 \%$ down payment. The plan is also beneficial to young working professionals and couples because it provides them with some financial cushion and allows them enough time to save for a period of 5 years. Then they can decide whether to buy in the sixth year. If the property price fell at that time, they could decide not to buy; but if the price rose, it would be a victory for the buyer. For home buyers, proper financial planning is always crucial before committing to purchasing a property.

Everyone wants to abolish the 5\% RPGT imposed on real homeowners in the 2020 budget, because it is said that this is actually an inflation tax. The government changed the 
calculation date of $5 \%$ from January 1, 2000 to January 1, 2013. This is a 13-year revision, which can be interpreted as good news. So now the $5 \%$ tax is much lower. But of course, the new law will only go into effect on January 1,2020 , so before that, real estate sellers may want to postpone any sales for the remaining year. At the same time, on June 5, 2020, the Prime Minister announced that the government will implement an RPGT exemption for the sale of residential properties from June 1, 2020 to December 31, 2021. The exemption is limited to the sale of three houses per person.

In addition, BSN MyHome is a youth housing program managed by the National Bank (BSN) to help single and married young people take the first step in owning property. The BSN MyHome Youth Housing Program provides properties ranging from RM100,000 to RM500,000 for eligible applicants between the ages of 21 and 45. This is another good measure to help young people get their first home. Applicants can obtain up to $100 \%$ loan financing based on the value of the property. It may not require down payment. BSN extended the program, also widely known as Skim Perumahan Belia (SPB), to December 31, 2020. The real estate market. $100 \%$ stamp duty exemption is up to RM300,000.00. The government provides monthly installment support of RM200.00 for the first two years. Up to $5 \%$ of MRTA financial support.

\section{Conclusion}

For most Malaysians, buying a house is very difficult. Affordable housing, financial support and HOC 2020 are good ways to reduce the cost of buying a new house. Owning a home that can truly be called one's own is the ultimate dream of almost anyone. But with rising real estate prices and loan repayment periods of 30 years or more, buying and financing a home is not just a matter of saying "I like it" and signing on the dotted line. However, what is often overlooked is the additional costs they need or may want to pay for new acquisitions. The real estate market has never been as vibrant as it is now. Government policies, an increasing number of organized participants, and the regulatory framework that are being implemented all require increased awareness and more education in order to take full advantage of the ever-changing era. Buying a property can be a daunting experience for first-time home buyers, second-time home buyers, and even property investors.

\section{Acknowledgements}

This research received full support from Universiti Putra Malaysia IPM Grant - Current Issues 9681400 (UPM RMC).

\section{References}

Ahsen, O., \& Gulcin, P.G. (2005). Space use, dwelling layout and housing quality: an example of low cost housing in Istanbul. England: Ashgate publishing Limited.

Doling, J. (2006). Home ownership and labour market participation of younger people. In: Horsewood N and Neuteboom P (eds) The social limits to growth: Security and insecurity aspects of home ownership. IOS Press BV, The Netherlands.

Fan. (2010) Housing Environment Preference of Young Consumers in Guangzhou, China. Property Management 28 (3), 174-192.

Hashim, Z. A. (2010). House Price and Affordability in Housing in Malaysia. Journal of Southeast Asia School Science and Humanities, 78, 2010, 37-46 
Hassan, M. M., Ahmad, N., \& Hashim, A. H. (2021a). Housing Purchase Decision: The Variations Type of Housing Development in Malaysia. International Journal of Academic Research in Business and Social Sciences, 11(7), 463-484.

Hassan, M. M., Ahmad, N., \& Hashim, A. H. (2021b). A Review on Housing Affordability in Malaysia: Are We Doing Fine? Malaysian Journal of Consumer and Family Economics, Vol 26, 2021.

Heath S (2008). Housing Choices and issues for young people in the UK. Joseph Rowntree Foundation. Available from: www.jrf.org.uk

Huang, Z., \& Du, X., (2015). Assessment and determinants of residential satisfaction with public housing in Hangzhou, China. Habitat International, 47, 2015, 218-230

Junaidi, A. B., Rosmadi, F., Amer, S. G. (2012) Penilaian awal impak perlaksanaan Dasar Perumahan Negara terhadap sector perumahan di Kuala Lumpur. Geografia-Malaysian Journal of Society \& Space 8 (6), 90-108.

Khalifah, A. A. K., Pandelaki, E. E., \& Rukayah, S. (2015). Consumer Preferenc in Type of House Appeance Offered by Housing Developer in Semarag. Teknik, 36(2), 2015, 91-95.

Mariadas, P. A., Abdullah, H., \& Abdullah, N. (2019). Factors Influencing the First Home Purchase Decision of Middle-Income earners (M40) in Selangor, Malaysia. Journal of Social Sciences \& Humanities, Vol. 16, No. 1(1-11). ISSN: 1823-884x.

National Housing Department. (2010), National Housing Policy, Ministry of Housing and Local Government.

Petrus, V. (2012). Study on the key factors influencing buyers' preferences for house purchase in Kota Kinabalu (Doctoral dissertation, Universiti Malaysia Sabah).

San, C. (2016). Attributes influencing homebuyers' purchase decision: A study of residential property in Setia Alam (Master's thesis, University Tunku Abdul Rahman, Kuala Lumpur).

Tan, T. H. (2009) Home owning motivation in Malaysia. Journal of Accounting, Business \& Management, 16 (1), $93-112$.

The Star Online, Bank Negara opens RM1bil home loan scheme to bigger group of first-time buyers. (2019). Retrieved October 11, 2019, from https://www.thestar.com.my/business/business-news/2019/08/21/bank-negaraopens-rm1bil-home-loan-scheme-to-bigger-group-of-first-time-buyers

Vliet, W. V. (1998). The Encyclopaedia of Housing. SAGE Publication, California.

Zaimah, R., Sarmila, M. S., Azimam, A. M., Suhana, S., Yusof, M. H., Lyndon, N. (2012) Kualiti hidup dan kesejahteraan belia: Kajian ke atas pekerja sector awam Malaysia. GeografiaMalaysian Journal of Society and Space 8 (6), 150-156.

Auction Properties: To buy or not to buy? (2020). Retrieved August 13, 2020, from https://www.iproperty.com.my/guides/auction-properties-to-buy-or-not-to-buy/

Government Housing Programs You Should Know About. (2015). Propsocail Editor. Retrieved April 11, 2020, from https://www.propsocial.my/topic/181/government-housingprograms-you-should-know-about-posted-by-propsocial-editor

The HOC (Home Ownership Campaign) 2020 - Extended! (2020). Retrieved August 13, 2020, from https://www.propertyguru.com.my/property-guides/home-ownershipcampaign-hoc-2020-all-you-need-to-know-15274

Subsale or New Launch Property - Which is better? (2020). Retrieved August 13, 2020, from https://www.iproperty.com.my/guides/subsale-or-new-launch-property-malaysia/

Under Construction Vs. Sub-sale Property: What to Consider? (2020). Retrieved August 13, 2020, from https://www.imoney.my/articles/under-construction-vs-sub-sale-propertywhat-to-consider 
What are the Upfront Costs of Buying a Home in Malaysia? (2019). Retrieved August 19, 2020, from https://www.imoney.my/articles/buy-house-in-malaysia

Youth City to Cater to Needs of Youth. (2014). Bernama News. Retrieved April 11, 2020 from: https://www.blueoceanstrategy.com/wp-content/uploads/2015/04/Bernama-25Sep2014-Youth-City-To-Cater-To-Needs-Of-Youth-Abdul-Rahman.pdf

4 Budget 2020 Initiatives Home Buyers Can Take Advantage Of. (2019). Retrieved April 4, 2020, from https://www.iproperty.com.my/guides/budget-2020-initiatives-homebuyers-can-take-advantage-of/

6 Property Market Trends to Expect in 2019. (2019). Retrieved August 13, 2020, from https://www.iproperty.com.my/news/6-property-market-trends-to-expect-in-2019/

7 Govt. Housing Schemes First-time Buyers Must Check Out. BBazaar by BBazaar. (2019). Retrieved April 11, 2020 from https://www.freemalaysiatoday.com/category/leisure/2019/03/31/7-govt-housingschemes-first-time-buyers-must-check-out/ 